\title{
ECTO- PARASITISM IN JUVENILE INDIAN MAJOR CARPS OF DIFFERENT FISH FARMS OF MYMENSINGH
}

\author{
D. R. Das ${ }^{1}$, S. Majumder ${ }^{2}$ and K. J. Chandra ${ }^{3}$ \\ ${ }^{1}$ Bangladesh Fisheries Research Institute, Floodplain Sub station, Santaher, Bogra; ${ }^{2}$ Department of Agricultural \\ Statistics, ${ }^{3}$ Department of Aquaculture, Bangladesh Agricultural University, Mymensingh
}

\begin{abstract}
An investigation was made on the ecto-parasitism of juvenile carps of Mymensingh region. Eight farms, four Government (Govt.) and four Private (Pvt.) fish farms were investigated for Indian major carps(Catla catla, Labeo rohita and Cirrhinus cirrhosus) (Catla, Rui and Mrigal) during June, 2010 to May, 2012. Monthly samplings were carried out with 5 fish from each species and each farms. Altogether 2880 fish hosts were examined of which 1674 were found to be infested with different groups of parasites during the study period. The ectoparasites were very common in gill, skin, mouth cavity, muscle, base of the pelvic, pectoral, anal, caudal fin and body surface of all fishes. Eleven species of protozoan, thirteen species of monogeneans and two species of argulus were recorded. The risk of being infestation by parasites in carps significantly $(\mathrm{p}<0.001)$ increased when the water quality parameters were deteriorated. Prevalence $(\%)$, mean intensity and abundance were found to be species specific and also varied with seasons and management systems practiced by different farmers. Prevalence (\%) of ecto-parasites in carps was significantly $(\mathrm{p}<0.001)$ higher in Pvt. farm than that of Govt. farms and was significantly $(\mathrm{p}<0.01)$ higher in rainy season. Rui was more susceptible than Catla and Mrigal.
\end{abstract}

Key words: Ecto-parasites, Infestations, Fish farms and Indian major carps

\section{INTRODUCTION}

Indian major carps (Catla catla, Labeo rohita and Cirrhinus cirrhosus) involved in aquaculture system from immemorial time in South-east Asian countries, including Bangladesh. Polyculture is the system in which fast growing compatible species of different feeding habits are stocked in different proportions in the same pond has been practicing from the very beginning of the fish culture in China and in Indian sub-continent (Jhingran, 1976). One of the major problems of fish culture is the parasitic infestation and disease. Fish parasites can cause mortalities of fishes in culture operations. They attack fishes and destroy them or make wounds or disease on their flesh, thus making them unedible. A number of parasitic diseases have been already been reported from our water bodies. Common protozoan parasitic diseases of freshwater fishes in Bangladesh are caused mainly due to Trichodina, Myxobolus, Chilodonella, Ichthyobodo, Ichthyophthiriasis and Myxosporidiasis. Amongst metazoans parasites, Dactylogyrus, Gyrodactylus, Argulus, Piscicola and Larnaea are very common (Banu et al., 1993).

In Bangladesh, information on prevalence and extent of damage caused by parasites in carp fry and fingerlings is scanty (Chandra, 2006). in order to control fish diseases caused by the parasites, it is essential to study their taxonomy to identify them, their infestations, as well as their effect on hosts. Therefore, the study of fish parasites is one of the significant and priority areas. Considering the above facts, the present investigation was undertaken to identify parasitic pathogens and their nature of position in juvenile farmed fishes.

\section{MATERIALS AND METHODS}

In total 2880 fish hosts of Catla, Rui and Mrigal were investigated in eight fish farms, 4 Government and 4 Private fish farms for examination during 24 months from June 2010 to May 2012. To observe the seasonal infestation, only distinct seasons were used which included rainy season, winter season and summer in the experimental period The experimental fishs were sampled regularly by visiting the experimental ponds. Samplings were carried out from the farms at monthly intervals. During each sampling 5 fishes from each species were collected every pond with the help of seine net. The collected infested fishes were brought live to the Fish Disease Laboratory, Department of Aquaculture, BAU by water containing in bucket.

*Corresponding e-mail address: drd4272@yahoo.com 


\section{D.R. Das and others}

Most of the ecto-parasites were recorded from the different partsof the fish body like pelvic, pectoral, anal, caudal regions, skin, gill regions, body surface, muscle and mouth cavity. In the laboratory fishes were killed by a blow on the head and only a little portion of the infested part of different regions were removed into petridish containing water and gently scrapped to dislodge live ecto-parasites (protozoans, monogeneans and argulus). They were removed on to clear slides with a fine pipette in a drop of water and covered with cover slip. Ammonium picrate solution was added beneath the cover slip to fix and clear the parasites. Four corners of the cover slips were then sealed with sealant to prevent it from moving. Then the slides were marked by a marker pen according to probable protozoans or monogenetic trematodes. Protozoans, monogenetic and Argulus were identified up to species whenever possible. Though it was most difficult to identify the myxosporidian protozoans with cyst but tried to identify only on the basis of its cyst morphology. Ten processed specimens were selected for measurement. Some microscopic photographs were taken by a camera attached to the microscope. The measurements were taken with the help of oculormicrometer adjusted with stage micrometer and the microscope (Gussev, 1976; Chandra, 2008).

\section{Identification}

Diseased fishes were collected from the selected water bodies and various symptoms of diseases were noted according to Amlacher, 1997. Identification and classification of the parasites were done following Gussev (1976), Woo (1999) and Chandra (2008). The ecological terms for prevalence (\%) and intensity of infestation were used after Margolis et al. (1982) as

Prevalence $=\frac{\text { No. of hosts infected }}{\text { No. of hosts examined }} \times 100$

Mean intensity $=\frac{\text { No. of parasites recovered }}{\text { No. of infected fish }}$

Abundance $=\frac{\text { No. of parasites recovered }}{\text { No. of host examined }}$

\section{Statistical analysis}

Prevalences of different ecto-parasites were computed by the following formula (Thrusfield, 1995): Chi-square and normal tests had been performed for testing the significance of the variation in prevalences of ecto-parasites, seasons and farms (Gupta, 2005). Comparison of two prevalences were made by normal test and chi-square test was used for examining the existence of overall significant differences among more than two prevalences, but their mutiple comparisons were done by Tukey-type test (Zar, 2003). In Tukey-type test, prevalences were transformed by the following arcsin transformation formula (Zar, 2003) due to its preference by many researchers:

$$
\begin{aligned}
& P^{\prime}=\frac{1}{2}\left[\arcsin \sqrt{\frac{X}{n+1}}+\arcsin \sqrt{\frac{X+1}{n+1}}\right] \\
& P^{\prime}=\text { Transformed proportion } \\
& X=\text { No. of infested fishes } \\
& n=\text { No. of examined fishes }
\end{aligned}
$$

Mean intensity and abundance of ecto-parasites in different types of juvenile carp fishes corresponding to the different seasons as well as farms were compared by Tukey tests (Zar, 2003). All the statistical analyses were done by SPSS (Statistical Package for Social Science) and MS Excel. 


\section{RESULTS AND DISCUSSION}

\section{Seasonal infestations of all parasites in different juvenile carp species}

Seasonal variation of ectoparasitic infestations were presented in (Table 1). In Govt. farms the higher prevalence (67.5\%), mean intensity (30.24) and abundance (20.41), whereas in Pvt. farms higher prevalence, mean intensity and abundance were $82.50 \%, 36.08$ and 28.41 respectively. However maximum infestations were recorded in Rui and Mrigal during rainy and winter seasons and minimum infestation were in summer in Catla both in Govt. and Pvt. farms. Each of the seasons exerts insignificant (p>.005) difference among the prevalences of all parasites in carp fishes of Govt. farm, but in rainy and winter seasons, the prevalences of these parasites in carp fishes in Pvt. farm vary significantly $(\mathrm{p}<0.05$ or $\mathrm{p}<0.001)$. The highest mean intensity and abundance (36.08 and 28.41) are found for Rui in rainy season in Pvt. farm.

Table 1. Seasonal infestations of all (group) ecto-parasites for combined 2 years data recorded in different carp species during June 2010 to May 2012

\begin{tabular}{|c|c|c|c|c|c|c|c|c|}
\hline \multirow[t]{2}{*}{ Seasons } & \multirow[t]{2}{*}{ Species } & \multicolumn{2}{|c|}{ No. of host fishes } & \multirow{2}{*}{$\begin{array}{c}\text { Total } \\
\text { load of } \\
\text { parasite }\end{array}$} & \multirow{2}{*}{$\begin{array}{c}\text { Prevalence (\%) } \\
\text { (Transformed } \\
\text { prevalence, \%) }\end{array}$} & \multirow{2}{*}{$\begin{array}{c}\chi^{2} \\
\text { (p-value) }\end{array}$} & \multirow{2}{*}{$\begin{array}{c}\text { Mean } \\
\text { intensity }\end{array}$} & \multirow[t]{2}{*}{ Abundance } \\
\hline & & Examined & Infested & & & & & \\
\hline \multicolumn{9}{|c|}{ Government fish farm } \\
\hline \multirow[t]{3}{*}{ Rainy } & Catla & 160 & 96 & 984 & 60.00 & \multirow{3}{*}{$\begin{array}{c}1.129 \\
(0.569)\end{array}$} & $10.25^{\mathrm{C}}$ & $6.15^{\mathrm{c}}$ \\
\hline & Rui & 160 & 108 & 3266 & 67.50 & & $30.24^{\mathrm{a}}$ & $20.41^{\mathrm{a}}$ \\
\hline & Mrigal & 160 & 106 & 2112 & 66.30 & & $19.92^{b}$ & $13.20^{\mathrm{b}}$ \\
\hline \multirow[t]{3}{*}{ Winter } & Catla & 160 & 68 & 664 & 42.50 & \multirow{3}{*}{$\begin{array}{c}2.536 \\
(0.281)\end{array}$} & $9.76^{\mathrm{C}}$ & $4.15^{\mathrm{bc}}$ \\
\hline & Rui & 160 & 76 & 1094 & 47.50 & & $14.39^{\mathrm{a}}$ & $6.84^{\mathrm{ab}}$ \\
\hline & Mrigal & 160 & 88 & 1210 & 55.00 & & $13.75^{\mathrm{ab}}$ & $7.56^{\mathrm{a}}$ \\
\hline \multirow[t]{3}{*}{ Summer } & Catla & 160 & 56 & 550 & 35.00 & \multirow{3}{*}{$\begin{array}{c}2.496 \\
(0.287)\end{array}$} & $9.82^{\mathrm{bc}}$ & $3.44^{\mathrm{bc}}$ \\
\hline & Rui & 160 & 74 & 1540 & 46.30 & & $20.81^{\mathrm{a}}$ & $9.63^{\mathrm{a}}$ \\
\hline & Mrigal & 160 & 72 & 1200 & 45.00 & & $16.67^{\mathrm{ab}}$ & $7.50^{\mathrm{ab}}$ \\
\hline Total & & 1440 & 744 & 12620 & 51.70 & & 16.96 & 8.76 \\
\hline \multicolumn{9}{|c|}{ Private fish farm } \\
\hline \multirow[t]{3}{*}{ Rainy } & Catla & 160 & 94 & 1510 & $58.75\left(49.98^{\mathrm{bc}}\right)$ & \multirow{3}{*}{$\begin{array}{l}7.542 * \\
(0.023)\end{array}$} & $16.06^{\mathrm{C}}$ & $9.44^{\mathrm{C}}$ \\
\hline & Rui & 160 & 126 & 4546 & $78.75\left(62.30^{\mathrm{a}}\right)$ & & $36.08^{\mathrm{a}}$ & $28.41^{\mathrm{a}}$ \\
\hline & Mrigal & 160 & 112 & 3478 & $70.00\left(56.73^{\mathrm{ab}}\right)$ & & $31.05^{\mathrm{ab}}$ & $21.74^{\mathrm{b}}$ \\
\hline \multirow[t]{3}{*}{ Winter } & Catla & 160 & 80 & 980 & $50.00\left(45.00^{\mathrm{C}}\right)$ & \multirow{3}{*}{$\begin{array}{c}19.285^{* * *} \\
(0.000)\end{array}$} & $12.25^{\mathrm{C}}$ & $6.13^{c}$ \\
\hline & Rui & 160 & 110 & 1724 & $68.75\left(55.87^{\mathrm{ab}}\right)$ & & $15.67^{\mathrm{ab}}$ & $10.78^{\mathrm{b}}$ \\
\hline & Mrigal & 160 & 132 & 2312 & $82.50\left(64.97^{a}\right)$ & & $17.52^{\mathrm{a}}$ & $14.45^{\mathrm{a}}$ \\
\hline \multirow[t]{3}{*}{ Summer } & Catla & 160 & 74 & 908 & $46.25\left(41.81^{\mathrm{bc}}\right)$ & \multirow{3}{*}{$\begin{array}{c}8.286 * * * \\
(0.000)\end{array}$} & $12.27^{\mathrm{C}}$ & $5.67^{\mathrm{C}}$ \\
\hline & Rui & 160 & 110 & 2658 & $68.75\left(55.87^{\mathrm{a}}\right.$ & & $24.16^{\mathrm{ab}}$ & $16.61^{\mathrm{a}}$ \\
\hline & Mrigal & 160 & 92 & 2330 & $57.50\left(49.26^{\mathrm{ab}}\right)$ & & $25.33^{\mathrm{a}}$ & $14.56^{\mathrm{ab}}$ \\
\hline Total & & 1440 & 930 & 20446 & 64.58 & & 21.98 & 14.20 \\
\hline
\end{tabular}

Level of Significance : ${ }^{*} \mathrm{p}<0.05$ and ${ }^{* * *} \mathrm{p}<0.001 .{ }^{1}$ Transformed prevalences are computed and compared (pairwise) only for significant chi-square values and any two of these prevalences in each season having no common letter are significantly different at $5 \%$ or $1 \%$ level of probability and the level selection depends upon the p-value of the corresponding chi-square. In each season, any two values of mean intensity and abundance having no common letter are significantly different at $5 \%$ level of probability.

\section{Seasonal variation of infestations of all parasites in carp fishes}

Infestations of all parasites in carp fishes was presented in Table 2. Both in Govt. and Pvt. farms infestations (prevalence, mean intensity and abundance) were higher in rainy seasons and only prevalence were lower in summer but mean intensity and abundance were found lower in winter season. The highest mean intensity and abundance (28.72 and 19.86) were recorded in the rainy season in Pvt. farms. It meant that all parasitic infestations were much heavier in Pvt. farms than Govt. farms. Therefore there exist a significant $(\mathrm{p}<0.05$ or $\mathrm{p}<0.001$ ) difference among the prevalence of all parasites in different seasons in Govt. as well as Pvt. farms. 


\section{D.R. Das and others}

Table 2. Seasonal variation of infestations of all parasites of combined 2 years in carp fishes during june, 2010 to May, 2012

\begin{tabular}{|c|c|c|c|c|c|c|c|c|}
\hline \multirow{2}{*}{$\begin{array}{l}\text { Farm } \\
\text { category }\end{array}$} & \multirow[t]{2}{*}{ Seasons } & \multicolumn{2}{|c|}{ No. of host fishes } & \multirow{2}{*}{$\begin{array}{c}\text { Total } \\
\text { load of } \\
\text { parasites }\end{array}$} & \multirow{2}{*}{$\begin{array}{l}\text { Prevalence \%) } \\
\text { (Transformed } \\
\text { prevalence, ) }{ }^{1}\end{array}$} & \multirow{2}{*}{$\begin{array}{l}\chi^{2}(\mathrm{p}- \\
\text { value })\end{array}$} & \multirow{2}{*}{$\begin{array}{c}\text { Mean } \\
\text { intensity }\end{array}$} & \multirow[t]{2}{*}{ Abundance } \\
\hline & & $\begin{array}{l}\text { Examin } \\
\text { ed }\end{array}$ & Infested & & & & & \\
\hline \multirow[t]{4}{*}{ Govt. } & Rainy & 480 & 310 & 6362 & $64.58\left(53.44^{\mathrm{a}}\right)$ & \multirow{3}{*}{$\begin{array}{l}25.929 * * \\
*(0.000)\end{array}$} & $20.52^{\mathrm{a}}$ & $13.25^{\mathrm{a}}$ \\
\hline & Winter & 480 & 232 & 2968 & $48.33\left(44.05^{b}\right)$ & & $12.79^{\mathrm{bc}}$ & $6.18^{\mathrm{bc}}$ \\
\hline & Summer & 480 & 202 & 3290 & $42.08\left(40.46^{\mathrm{bc}}\right)$ & & $16.29^{b}$ & $6.85^{b}$ \\
\hline & Total & 1440 & 744 & 12620 & 51.67 & & 16.96 & 8.76 \\
\hline \multirow[t]{4}{*}{ Pvt. } & Rainy & 480 & 332 & 9534 & $69.17\left(56.22^{\mathrm{a}}\right)$ & \multirow{3}{*}{$\begin{array}{l}8.124 * \\
(0.017)\end{array}$} & $28.72^{\mathrm{a}}$ & $19.86^{\mathrm{a}}$ \\
\hline & Winter & 480 & 322 & 5016 & $67.08\left(54.95^{\mathrm{ab}}\right)$ & & $15.58^{\mathrm{C}}$ & $10.45^{\mathrm{bc}}$ \\
\hline & Summer & 480 & 276 & 5896 & $57.50\left(49.29^{\mathrm{bc}}\right)$ & & $21.36^{\mathrm{b}}$ & $12.28^{\mathrm{b}}$ \\
\hline & Total & 1440 & 930 & 20446 & 64.58 & & 21.98 & 14.20 \\
\hline \multirow[t]{4}{*}{ Combined } & Rainy & 960 & 642 & 15896 & $66.88\left(54.84^{\mathrm{a}}\right)$ & \multirow{3}{*}{$\begin{array}{c}28.828 * * * \\
(0.000)\end{array}$} & $24.76^{\mathrm{a}}$ & $16.56^{\mathrm{a}}$ \\
\hline & Winter & 960 & 554 & 7984 & $57.71\left(49.42^{b}\right)$ & & $14.41^{\mathrm{C}}$ & $8.32^{\mathrm{bc}}$ \\
\hline & Summer & 960 & 478 & 9186 & $49.79\left(44.88^{c}\right)$ & & $19.22^{b}$ & $9.57^{b}$ \\
\hline & Total & 2880 & 1674 & 33066 & 58.13 & & 19.75 & 11.48 \\
\hline
\end{tabular}

Level of Significance : ${ }^{*} \mathrm{p}<0.05$ and ${ }^{* * *} \mathrm{p}<0.001 .{ }^{1}$ Transformed prevalences are computed and compared (pairwise) only for significant chi-square values and any two of these prevalences in each farm category having no common letter are significantly different at $5 \%$ or $1 \%$ level of probability and the level selection depends upon the p-value of the corresponding chi-square. In each farm category, any two values of mean intensity and abundance having no common letter are significantly different at $5 \%$ level of probability.

\section{Infestations of all parasites in carp fishes in different farms}

Among the farms the higher prevalence were found in Sornalota Pvt. farm and mean intensity and abundance were found higher in Deshbandhu Pvt. farm and the lowest prevalence, mean intensity and abundance were found in BFRI Govt. farm. Table 3 revealed that farm based prevalences of all parasites in carp fishes differ insignificantly ( $>0.05$ ) within the Govt. farm as well as Pvt. farms, but there existed a significant difference between the prevalences (51.67\% and $64.58 \%$ ) of these two different of farms. The highest mean intensity and abundance (22.77 and 14.54) were recorded for Deshbandhu Pvt. farm.

Table 3. Infestations of all parasites combined in 2 years in juvenile carp fishes in different farms during June, 2010 to May, 2012

\begin{tabular}{|c|c|c|c|c|c|c|c|c|c|}
\hline \multirow{2}{*}{ 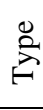 } & \multirow{2}{*}{$\begin{array}{l}\text { Name of the } \\
\text { farm }\end{array}$} & \multicolumn{2}{|c|}{ No. of the host Fishes } & \multirow{2}{*}{$\begin{array}{c}\text { Total } \\
\text { load of } \\
\text { parasites }\end{array}$} & \multirow{2}{*}{$\begin{array}{c}\text { Prevalence } \\
(\%)\end{array}$} & \multirow{2}{*}{$\begin{array}{l}\chi_{(\mathrm{p}-}^{2} \\
\text { value })\end{array}$} & \multirow{2}{*}{\begin{tabular}{|c} 
Z- \\
statistic \\
(p-value)
\end{tabular}} & \multirow{2}{*}{$\begin{array}{c}\text { Mean } \\
\text { intensity }\end{array}$} & \multirow[t]{2}{*}{ Abundance } \\
\hline & & Examined & Infested & & & & & & \\
\hline \multirow{4}{*}{ O } & BFRI & 360 & 170 & 2312 & 47.22 & \multirow{5}{*}{$\begin{array}{c}2.314 \\
(0.510)\end{array}$} & \multirow{5}{*}{$\begin{array}{c}4.965 * * * \\
(0.000)\end{array}$} & $13.60^{\mathrm{bc}}$ & $6.42^{\mathrm{bc}}$ \\
\hline & Maskanda & 360 & 186 & 3250 & 51.67 & & & $17.47^{\mathrm{ab}}$ & $9.03^{\mathrm{ab}}$ \\
\hline & Sombhugonj & 360 & 198 & 3916 & 55.00 & & & $19.78^{\mathrm{a}}$ & $10.88^{\mathrm{a}}$ \\
\hline & Gouripur & 360 & 190 & 3142 & 52.78 & & & $16.54^{\mathrm{ac}}$ & $8.73^{\mathrm{ac}}$ \\
\hline & Total & 1440 & 744 & 12620 & 51.67 & & & 16.96 & 8.76 \\
\hline \multirow{5}{*}{$\frac{5}{2}$} & \begin{tabular}{|l|} 
Brahmaputra \\
\end{tabular} & 360 & 230 & 4820 & 63.89 & \multirow{4}{*}{$\begin{array}{r}0.261 \\
(0.967)\end{array}$} & & $20.96^{\mathrm{ad}}$ & $13.69^{\mathrm{ad}}$ \\
\hline & Deshbandhu & 360 & 230 & 5236 & 63.89 & & & $22.77^{\mathrm{a}}$ & $14.54^{\mathrm{a}}$ \\
\hline & Pankouri & 360 & 232 & 5176 & 64.44 & & & $22.31^{\mathrm{ab}}$ & $14.38^{\mathrm{ac}}$ \\
\hline & Sornalota & 360 & 238 & 5214 & 66.11 & & & $21.91^{\mathrm{ac}}$ & $14.48^{\mathrm{ab}}$ \\
\hline & Total & 1440 & 930 & 20446 & 64.58 & & & 21.98 & 14.20 \\
\hline
\end{tabular}

Level of Significance: $* * * \mathrm{p}<0.001$. Any two values of mean intensity and abundance in each farm category, having common letter are not significantly different at $5 \%$ level of probability. 
In the present study, it was observed that infestation of different parasites in different months varied at various levels. Prevalence, abundance and mean densities of these ectoparasites were also observed and found to vary from season to season in the present work. The parasites were isolated from body slime/skin, gill and fin in different carp species. Whitish to yellowish cysts in the skin and gill, loss of mucus, slight haemorrhage at the base of dorsal, pectoral and caudal fin were observed in case of heavily infected fish. Subasinghe (1992) studied hatchery diseases of freshwater fish in Sri Lanka and reported heavy mortality in major carp fry and fingerlings due to ciliate ectoparasite like Trichodina sp., Ichthyophthirius sp., Chilodonella sp., Myxobolus sp. and fluke like Dactylogyrus sp. during nursery operation.

Rainy and winter months were the most susceptible period of the year when fish parasites were found abundant. This could be due to stocking density, water depth, temperature along with other physico-chemical parameters and management practices maintained. Banu and Khan (2004); Mohan and Bhatta (2002) reported that ectoparasites are some of the very important pathogens that have had significant impact on the yield in carp hatcheries and seed production centres.

In the present study, Pvt. farms were found to be more affected by parasitic diseases compared to Govt. farm. Among private farms, Sornalata was more infected and Brahmaputr Pvt. farm was less infected, in Govt. farms, Sombhugonj was more infected and BFRI Govt. farm was less infected by parasitic diseases. The causes of higher/lower infestation in prevarence mean intensity or abundance were different due to different nature of management practices like pond preparation, depth of water, transparency, stocking density, feeding of fry/fingerlings etc. Chandra (1987) stated that the unfavourable envrronmental/ ecological conditions caused variety of fish diseases. Because water qua1ity, pond condition, stress from poor environmental conditions and waste product are excess in Private Farm. Whereas the pond condition were comparatively better in BFRI. Akter et al. (2007) also observed more or less similar to the present study.

Prevalence of all parasites in carp fishes was significantly $(\mathrm{p}<0.001)$ higher in Pvt. farm than that of Govt. farm. The prevalence of all these parasites were higher in rainy season than the summer seasons. But the prevalence of this season differed significantly $(\mathrm{p}<0.05)$ only with summer not with winter. Rui and Mrigal were more infected than Catla. But the prevalence differed significantly $(\mathrm{p}<0.05)$ between Rui and Catla. This might be associated with the better management of the Govt. farms and mid - level and bottom dwelling nature of Rui and Mrigal. Almost identical observations were made by Bhuiyan et al. (2010).

Mean intensity and abundance was highest in C. cirrhosus and L. rohita collected from private Fish Farm and lowest in C. catla collected from Govt. Fish Farm. It might be due to higher stocking density in Pvt. Fish Farm. Several authors have noted the correlation between outbreak of disease and stocking density (Johnsen and Jensen, 1986). Almost similar result was reported by Barai et al. (2005) and Bakshi et al. (2006). They studied parasitic infestation of indigenous major carp from different areas of Mymensingh district and observed maximum infestation in $C$. cirrhosus and $L$. rohita. This may be correlated with the bottom and middle dwelling habit of $C$. cirrhosus and $L$. rohita and its comparatively slower movement in the habitat which may allow ectoparasites quick transmission from one host to another.

During the period of investigation, infestation was changed with seasonal variation. The total parasitic infection was the highest in rainy and lowest in summer season. This result agrees with (Hossain et al., 2007; Banerjee and Bandyopadhyay, 2010). Golder et al. (1987) observed that the average incidence of infestation during winter season was lower. Bhuiyan and Musa (2008) reported that the highest ectoparasitic infection in carp fry and fiingerlings were in August and September because of the highest stocking density the highest average incidence of infestation found in summers and lower in winter. It could be due to higher stocking density lower water depth and temperature rising just after winter. Chandra (1987) mentioned that increased occurrence of disease in the rainy season might again be due to unfavourable environmental condition.

It may be concluded from the present investigation that juvenile indian major carps can be infested by ectoparasites throughout the year and they have a continuous process of recruitment and infection to host fish with certain variation in different seasons, farms and species of the year. The ectoparasites were very common in gill, skin, mouth cavity, muscle, base of the pelvic, pectoral, anal, caudal fin and body surface of all fishes. Private farm owners used haphazardous types of management practices and were found more infestations. Ecto-parasitic infestations were more severe in Rui. As the host seems to be more susceptible during rainy season, proper care may be taken including natural feeding to prevent their infestations during this period for susceptible carp culture. 


\section{D.R. Das and others}

\section{ACKNOWLEDGEMENTS}

Financial support provided by the National Agricultural Technology Project (NATP): Phas-1, Project Implementation Unit (PIU) of BARC funded project on for conducting the research work is gratefully acknowledged.

\section{REFERENCES}

1. Akter MA, Hossain MD and Rahman MR (2007). Parasitic diseases of carp fry in Bangladesh. Journal of Agricculture and Rural Development 5: 127-134.

2. $\quad$ Amlacher E (1997). Text book of fish diseases: Narendra Publ. House, Delhi, India. pp. 302.

3. Bakshi AK, Chandra KJ and Hoque N (2006). Argulosis in the fish culture ponds of selected areas of Mymensingh. Journal of Bangladesh Agricultural University 4: 305-312.

4. Banerjee S and Bandyopadhyay PK (2010). Observation on prevalence of ectoparasites in carp fingerlings in two districts of West Bengal. Journal of Parasitic Diseases 34: 44 - 47.

5. Banu ANH, Hossain MA and Khan MH (1993). Investigation into the occurrence of parasites in carps, catfish and tilapia. Progressive Agriculture 4: 11-16.

6. Banu ANH and Khan MH (2004). Water quality, stocking density and parasites of freshwater fish in four selected areas of Bangladesh. Pakistan Journal of Biological Sciences 7: 436 - 440.

7. Barai AK, Chandra KJ and Majumder S (2005). Population ecology and Infestation of monogenetic trematodes in Juvenile carps fish of Mymensingh. Journal of Bangladesh Agricultural University 3: 121-131.

8. Bhuiyan AS, Akther S and Amena NE (2010). Seasonal occurrence of parasites of the major carp, Cirrhina mrigala (Hamilton) collected from Rajshahi, Bangladesh. University Journal of Zoology of Rajshahi University 29: 47-50.

9. Bhuiyan AS and Musa AM (2008). Seasonal prevalence and intensity of infestation by the ectoparasites in carps relating to physico-chemical parameters in some ponds of Mymensingh and Bogra Districts of Bangladesh. Bangladesh Journal of Scientific and Industrial Research 43: 411-418.

10. Chandra KJ (1987). Fish health monitoring and control of disease. In: Training manual of training officer, DOF, Bangladesh September 1987. BFRI, Mymensingh. Training manual No. 1, pp. 155.

11. Chandra KJ (2006). A review of fish parasitological studies in Bangladesh. Journal of Agriculture \& Rural Development 4: 9-18.

12. Chandra KJ (2008). A Practical Text Book of fish Parasitology and Health Management. The University Grants commission of Bangladesh. pp. 213.

13. Cheng TC (1964). The Biology of Animal parasites. W.B. Saunders Company. Philadelphia and London, pp. 369.

14. Ferdousi UK and Chandra KJ (2002). Monogenean gill parasites of Oreochromis niloticus (Linn.) and Oreochromis mossambicus (Peters) Mymensingh, Bangladesh. Rivista Di Parassitologia XIX (LXIII) N. 1: 49-60.

15. Golder MI, Chandra KJ and Rahman AKA (1987). Helminth parasitism in Nandus nandus (Hamilton). Bangladesh Journal of Fisheries 10: 11-22.

16. Gupta SC (2005). Fundamentals of Statistics. Himalaya publishing house, Mumbai. $6^{\text {th }}$ revised and Enlarged ed. pp. 18.23-18.26.

17. Gussev AV (1976). Freshwater Indian Monogenoidea, principles of systamatics, analysis of the world fanus and their evaluation. Indian Journal of Helminthology 25/26: 1-241.

18. Hossain MD, Hossain MK and Rahman MH (2007). Water quality parameters and incidence of fish diseases in some Water bodies in Natore, Bangladesh. Journal of Life Earth Sciences 2: 27-30.

19. Jhingran VG (1976). System of polyculture in inland waters in India. Journal of Fisheries Research Board of Canada 33: 905-910.

20. Johnsen BO and Jensen A J (1986). Infestation of Atlantic Salmo salar by Gyrodactylus salaris in Norwegian rivers. Journal of Fisheries Biology 29: 233-214.

21. Margolis L, Esch GW, Holmes JC, Kuris AM and Schad GA (1982). The use of Ecological Terms in Parasitology (report of AN AD Hoc) Committee of the American Society of Parasitologgists. Journal of Parasite 68: 131-133.

22. Mohan CV and Bhatta R (2002). Social and economic impacts of aquatic animal health problems on aquaculture in India. In: J. R. Arthur, M. J. Phillips, R. P. Subasinghe, M.B. Reantaso and I. H. MacRac. (eds.). Primary Aquatic Animal Health Care in Rural, Small-Scale. Aquaculture Development. FAO FISH. TECH. Pap. No. 406, pp. 63-75.

23. Subasinghe RP (1992). Hatchery disease of freshwater fishes in Srilanka. In: Diseases in Asian Aquculture I, eds. M. Sharif, R. P. Subashinghe and J.R. Arthur, Asian Fisheries Society, Philippines. pp. 12-43.

24. Thrusfield M (1995). Veterinary Epidemiology. Blackwell science Ltd. $2^{\text {nd }}$ ed. London. pp. 39-41.

25. Woo PTK (1999). Fish diseases and disorders (Eds. Vol. 1.). Protozoan and metazoan infections. CABI Publishing. pp. 808.

26. Zar JH (2003). Biostatistical analysis. Pearson education (Singapore) Pte. Ltd. Singapore. pp. 208-214, 278-280, 563-565, APP 64. 